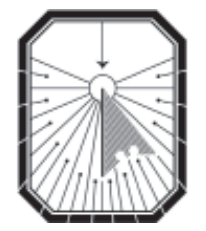

KYIV-MOHYLA

HuMANiTiES JOURNAL

KYIV-MOHYLA SCHOLARLY PEER-REVIEWED JOURNALS

The Stone Host, Lesia Ukrainka’s “Spanish” Play

Author(s): Oleksandr Pronkevich

Source: Kyiv-Mohyla Humanities Journal 8 (2021): 16-32

Published by: National University of Kyiv-Mohyla Academy

http://kmhj.ukma.edu.ua/ 


\title{
The Stone Host, Lesia Ukrainka's “Spanish” Play
}

\author{
Oleksandr Pronkevich \\ Petro Mohyla Black Sea National University, \\ Department of English Philology
}

\begin{abstract}
The article provides an analysis of the "Spanish code" inscribed in the text of Lesia Ukrainka's drama Kaminnyi hospodar (The Stone Host). The constituents of the code include: 1) conventions of 17 th century Spanish baroque drama, in particular, use of the dialectics of the concepts of dignity and reputation as a driving mechanism for conflict throughout Lesia Ukrainka's play and transformation within the classical scheme of characters suggested by Lope de Vega and his followers; 2) stereotypes of "Spanishness" through which the playwright produced a heteroimage of Spain. Lesia Ukrainka's variant of the famous legend of Don Juan is a sophisticated modernist drama. The "Spanish code" serves as a prism through which the playwright examines the world. Lesia Ukrainka created an astonishing modernist tragicomedy of dishonesty, full of the spirit of uncertainty.
\end{abstract}

Key Words: Lesia Ukrainka, Spanish code, conventions of 17th century Spanish baroque drama, stereotypes of "Spanishness," intertextuality, imagology.

\section{(2)}

The definition of Lesia Ukrainka's Kaminnyi hospodar (1912; The Stone Host) as a "Spanish play" was coined by Oksana Zabuzhko in her book Notre Dame D'Ukraine: Ukrainka in Conflict of Mythologies: "Let us call it Spanish, following the same logic which in England is used to define Macbeth as the Scottish play." The strongest evidence to prove this statement is the fact that Lesia Ukrainka was familiar with The Trickster of Seville or The Stone Guest, attributed to Tirso de Molina, and Don Juan Tenorio by José Zorilla, and developed a number of motifs from both works when creating "a Ukrainian variant of the world legend about Don Juan," as she stresses in her letter to Liudmyla Starytska-Cherniakhivska. ${ }^{2}$ As a result, the play presents an original reincarnation of the Trickster of Seville. For English speaking readers who may be not familiar with Lesia Ukrainka's drama it makes sense to introduce its plot and characters.

In Act I Don Juan is engaged to Dolores, but this circumstance does not prevent him from seducing other women. Dolores tells Donna Anna that her fiancé has been expelled from society for his crimes and is living in Cádiz among bandits and smugglers. Donna Anna is engaged to don Gonzago de Mendoza, the Commander. She is fascinated by Don Juan's bravery and listens to Dolores's account with great interest. The "dangerous" man appears and falls in love with Donna Anna. The lady, impressed by

$1 \quad$ Oksana Zabuzhko, Notre Dame D’Ukraine: Ukrainka v konflikti mifolohiy [Norte Dame D'Ukraine: Ukrainka in a Conflict of Mythologies] (Kyiv: Fakt, 2007), 398.

2 Lesia Ukrainka, Lysty: 1903-1913 [Letters, 1903-1913] (Kyiv: Komora, 2018), 593. 
the spirit of freedom that he personifies, and flattered by his attention to her, starts flirting with him. Their romance develops during the carnival in Act II. In Act III, set in the caves of Cádiz, Dolores comes to Don Juan and informs him that she has bought the King's forgiveness for him by selling her honor. She declares their engagement broken and enters a convent. Don Juan is free to leave for Madrid to see his beloved Donna Anna. The action in Acts IV, V, and VI takes place in the Spanish capital. Donna Anna, already married to the Commander, enjoys the privileges of aristocratic life. At the same time, she suffers from stony Castilian etiquette. The lady receives Don Juan secretly in her room when the Commander is out, but Don Gonzago de Mendoza returns unexpectedly and is killed by Don Juan when Donna Anna distracts her husband's attention. The protagonists meet at a cemetery near the Commander's statue. Don Juan implores Donna Anna to reciprocate his love. After profound internal struggle she surrenders and invites Don Juan to take supper in Don Mendoza's house. Don Juan asks his servant Sganarel to go to the Commander's statue to inform him about the invitation. The Commander nods and gives his answer in writing: "Come to me! I await thee!" Donna Anna decides to stay with Don Juan despite the fact that their relationship is inappropriate and is taken by Don Mendoza's family as a humiliation. She even decides to make Don Juan the new Host of Don Gonzago's house by forcing her lover to put on the Commander's coat. Anna gives him the Commander's sword, baton, and helmet. Both characters approach a mirror to admire themselves in it. The statue of the Commander steps out from the mirror and kills Don Juan. Donna Anna is allowed to remain alive: she screams and falls face down at the feet of the Commander.

In my article I would like to suggest some new arguments in favor of the "Spanishness" of the play and to provide my understanding of The Stone Host based on "the Spanish code" inscribed in Lesia Ukrainka's text. At first glance, Lesia Ukrainka pretends to deny the fact that the protagonists of her work are Spaniards. In a footnote, which comments on the presentation of the Dramatis personae, she stresses that the name Don Juan is to be pronounced in the French way - as [Zhuan] and not in the Spanish manner [Juan], because this practice "has been consecrated by an age-old tradition in world literature. For the same reason, in the play we choose the Italian form of the word donna."3 Moreover, the name of the heroine is also spelled with a double "nn" (in Spanish it is "Ana"). Through this verbal game Lesia Ukrainka wants to emphasize the universal (not necessarily Spanish) messages of her play.

And yet, The Stone Host is one of the few "Spanish" works of literature written in the Ukrainian language. This is due to several reasons. First, in spite of the "nonSpanish" spelling of names, the whole Don Juan legend is nevertheless associated with Spain. Second, Lesia Ukrainka, consciously or unconsciously follows some of the most important elements of 17 th century Spanish baroque drama conventions. Third, it must not be forgotten that the action is set in Spain. In the play one can find many references to Spanish culture and various types of ethnic and cultural identities of the 
people who live in the country. However, not all components of the "Spanishness" of The Stone Host have been equally analyzed by scholars. If the comparison of Lesia Ukrainka's play with Tirso's primary source has become commonplace in Ukrainian literary studies, ${ }^{4}$ two other aspects mentioned above have not yet drawn researchers' attention. It is this circumstance that determines my decision to focus on them.

Solving this problem requires a complex methodology. To reveal the intertextual connections between the poetics of The Stone Host and 17th century Spanish baroque drama, I will use a comparative perspective in order to clarify to what extent Lesia Ukrainka was "influenced" by ideas concerning how to compose plays proposed by Lope de Vega in the treatise El arte Nuevo de hacer comedias en este tiempo (The New Art of Writing Plays in this Age), 1609, and further developed by his followers. I will then try to restore the hetero-image of Spain created in The Stone Host. To do this I will apply the imagological method. I will build my textual analysis by comparing Lesia Ukrainka's original Ukrainian text ${ }^{5}$ with its English translation by Vira Rich, ${ }^{6}$ and finally with its Spanish version by Petro Kluk in cooperation with Prof. Carlos Jiménez. ${ }^{7}$

Spanish baroque drama flourished in the 17th century and left a profound imprint on the history of literature. In particular, it brought a new approach to writing plays. This theatrical revolution was started by Lope de Vega and was continued by famous

4 Robert Karpiak, "Don Juan in Slavic Drama," (PhD diss., University of Ottawa, 1977), 124-46; Olha Bohovin, "Krytychna retseptsiia dramy Lesi Ukrainky 'Kaminnnyi hosopdar' u XX-XXI st.: istoriohrafichni pytannia [Critical Reception of Lesia Ukrainka's The Stone Host in the 2oth and 21st Centuries: Historiographical Issues]," Naukovi zapysky Natisonalnoho universytetu Ostrozka akademiia. Seriia Filolohichna 41 (2014): 202-06; Ida Zhuravska, Lesia Ukrainka i zarubizhni literatury [Lesia Ukrainka and Foreign Literatures] (Kyiv: Vydavnytstvo Akademii Nauk Ukrainy, 1963); Kaminnyi hopodar Lesi Ukrainky i fenomen Serednovichchia [Lesia Ukrainka's The Stone Host and the Phenomenon of the Middle Ages], eds. Yaroslav Polishchuk and Anatoliiy Krylovets (Rivne: Perspektyva, 1998); Roman Kukhar, Do dzherel dramaturhii Lesi Ukrainky [On the Origins of Lesia Ukrainka's Dramas] (Nizhyn: Nizhynskyi derzhavnyi pedahohichnyi universytet im. M. Hoholia, 20oo); Yevhen Nenadkevych, "Ukrainska versiia svitovoii temy pro Don Zhuana v istoryko-literaturnii perspektyvi [The Ukrainian Version of the Universal Legend of Don Juan from the Literary and Historical Perspectives]," in Lesia Ukrainka, Tvory, ed. Borys Yakubskyi, vol. 11 (Kyiv: Knyhospilka, 1929): 7-42; Marta Reda, "Obraz Don Zhuana u tvorchosti Lesi Ukrianky u konteksti yevropeiskoi donzhuaniany [The Image of Don Juan in the Works of Lesia Ukrainka in the Context of the European Tradition of the Don Juan Legend]," Roczniki Humanistyczne, tom LIV-LV, zeszyt 7 (2006-2007): 83-95; Yaroslav Rozumnyi, "Vid 'sevilskoho oshukantsia' do ukrainskoho Don Zhuana [From the Trickster of Seville to the Ukrainian Don Juan]," Slovo i chas 6 (1993): $25-29$.

5 Ukrainka, Kaminnyi hospodar, 545-642.

6 Lesya Ukrainka, The Stone Host, translated by Vira Rich, in Lesya Ukrainka. Life and Works, ed. Constantine Bida (Toronto: University of Toronto Press, 1968): 87-142. Lesia Ukrainka, Dueño de piedra, in Lesia Ukraïnka in Translations, ed. Natalia Pazuniak (Philadelphia: The Commemorative Committee to Honor Lesia Ukrainka, 1988), 195-252. 
playwrights such as Tirso de Molina, Pedro Calderón de la Barca, and many others. Spanish baroque drama influenced 17th century French theatre and world theatre as a whole. Ignacio Arellano summarizes the most important "recommendations" of Lope de Vega concerning writing comedies. The Spanish playwright advises authors to 1) delete borders between comic and tragic, 2) disregard rules regulating the dramatic unities of time, space and action, 3) divide plays into three acts (jornadas), 4) use pure, simple, and flexible language, appropriate to the dramatic situations, 5) create the impression of verisimilitude through stage settings, 5) focus on two main subjects dignity or virtuous acts (el honor) and reputation (la honra), 6) introduce six main types of characters: A Beautiful Lady (Dama), A Young Gentleman (Galán), A Representative of Power (Poderoso), An Old Man (Viejo), The Young Gentleman's Servant (Gracioso), The Young Lady's Servant (la criada) ${ }^{8}$.

Although Lesia Ukrainka did not comment on the conventions of 17th century Spanish baroque drama in her works about theatre, she was definitely very well informed about them. If we suppose that the Ukrainian playwright read The Trickster of Seville or The Stone Guest (which historians of literature accept as fact), she could see their practical implementation in this play or in many other comedies by Lope de Vega, Tirso de Molina, and Calderón, which were all popular at the end of the 19th beginning of the zoth centuries. By the time Lesia Ukrainka had decided to create her own legend of Don Juan, these works had become an integral part of what Mikhail Bakhtin defines as "genre memory":

A genre lives in the present, but always remembers its past, its beginning. Genre is a representative of creative memory in the process of literary development. Precisely for this reason genre is capable of guaranteeing the unity and uninterrupted continuity of this development. ${ }^{9}$

The Stone Host very much looks like a play which follows the above-mentioned conventions of the poetics of 17th century Spanish baroque drama. With the only exception being the division of the play into 3 acts, The Stone Host reproduces all other elements of the comedia nueva. If some conventions, such as 1, 2, and 4, had become common practices of the late 19th century European Post-Romantic and New Drama theatre and had lost their direct connection to any particular national tradition, other conventions (especially 4 and 5 ) contribute to producing the Spanish atmosphere of Lesia Ukrainka's play.

In many senses, The Stone Host is a drama about dignity and reputation. In the Spanish language both concepts are expressed with words that sound similar, however,

8 Ignacio Arellano, Historia del teatro español del siglo XVII, Quinta edición (Madrid: Cátedra, 2012), 120-29.

9 Mikhail Bakhtin, Problems of Dostoevsky's Poetics (Minneapolis; London: University of Minnesota Press, 1984), 106. 
they have different meanings despite referring to interrelated things: el honor and la honra. The first concept denominates a set of virtues, a code of behavior, and a product of blood purity, which an individual inherits from ancestors. It is a distinguishing feature of aristocrats, although representatives of lower classes, such as Pedro Crespo in Calderón's The Mayor of Zalamea (El Alcalde de Zalamea), also deserve respect with their highly developed sense of dignity. The other concept is what public opinion holds about a person's reputation in accordance with regulations (very often unwritten) established by society. It is a personal and subjective quality. The loss of reputation, for example, when a woman is violated, leads to the loss of dignity of not only the victim herself but also of the person (father or brother or husband) who is supposed to protect her. Revenge on an abuser as the only possible remedy to restoring honor of the abused woman constitutes one of the most popular plots of 17th century Spanish baroque theatre as a whole and of Tirso de Molina's Trickster of Seville or The Stone Guest in particular. Commenting on the universal presence of the concepts of dignity (el honor) and reputation (la honra) in Spanish dramas of the 17th century, Ignacio Arellano states:

In serious comedies it is identical to life itself, it is a strict requirement for a representative of aristocracy, whose duty is to avenge his reputation if he loses it, by killing its violator with the only exception of the king; at the same time, it is a source of comedic situations in other genres. ${ }^{10}$

Of aristocratic family origin, Lesia Ukrainka proves to be very sensitive to the notions of lytsarstvo (chivalric values) and chest (dignity, honor). It is not therefore surprising that the Ukrainian playwright found an original approach to the figure of Don Juan. In a letter to Ahatanhel Krymskyi, Lesia Ukrainka terms Juan as lytsar voli" (a knight of freedom). The phrase sounds enigmatic because her Don Juan does not possess any freedom. Donna Anna manipulates him and he obeys. She says: "You have no freedom. For long ago Dolores took it from you." ${ }^{12}$ Another letter addressed to Olha Kobylianska contains an important nuance, which can help understand Lesia Ukrainka's remark concerning the protagonist: “...I did not want to add something new to the established interpretation of Don Juan's type, I only wanted to stress the out-ofcontrol character of his personality (anarkhichnist yoho vdachi)."13 The statement provides reasons to suggest that lytsar voli denotes "knight of anarchy," a representative of ethics based on egoism who rejects laws and regulations, and undermines the very

10 Ignacio Arellano, Historia del teatro español del siglo XVII, 126 ("En la comedia sería se identifica con la misma vida, exigencia rígida para el noble, que está obligado a vengar su honor, si lo pierde, con la muerte del deshonrador - con la única excepción del rey -; tiene, en cambio, tratamientos humorísticos en otros géneros").

11 Ukrainka, Lysty: 1903-1913, 592.

12 Ukrainka, The Stone Host, 138.

13 Ukrainka, Lysty: 1903-1913, 672-73. 
principle of the chivalric code of behavior. Donna Anna puts the same idea another way: "You, knightly champion of freedom, were in banishment a bandit." ${ }^{14}$

In any case, the dialectics of the concepts of dignity and reputation are a driving mechanism for the conflict present throughout Lesia Ukrainka's The Stone Host, which in terms of $17^{\text {th }}$ century Spanish baroque theatre can be interpreted as a "serious comedy," a drama which combines features of tragedy and comedy. The understanding of dignity as a specific code of conduct established by society is shared by practically all characters of the play, not only by aristocrats Donna Anna, the Commander, Dolores, Don Juan and others, but also by the servants, in particular, by Sganarel, who in Act III tells his master that he (Don Juan) does not correspond with the moral standard of a real gentleman. In the play Don Juan is presented as a Spanish Grandee, whose dignity is damaged by the King's decision to exile him for his behavior, which is not appropriate for his high social status. The fact that he is banished places him much lower in the social hierarchy than the Commander. He despises Don Juan as an "outlaw whom the King deprived / of honor and privilege." ${ }^{15}$ A duel with such a dishonored person would mean humiliation for Don Gonzago de Mendoza: "It is not fitting a Commander's honor / To duel with outlaws." ${ }^{16}$ Dolores, dressed as Black Domino, shares the same understanding of dignity as a strict code of chivalric behavior. When Don Juan follows the Commander, wanting to run him through with a rapier from the back, Dolores says that attacking like this is "dishonorable"17 ("No es noble atacar por la espalda"18).

The concept of reputation (honor, la honra) is also present in Lesia Ukrainka's play. Don Juan insists that he does not use violence and "conquers" women with his eloquence and charm. In his conversation with Donna Anna he stresses that she should not be afraid of being raped: "I'd not use force / To make attempts upon your honor. Do / Not fear, I don't eat women!"19 It is worth noticing that the semantic of cannibalism in the description of what Don Juan does to women is absent in the original. The protagonist says: "Ya zh bo sylomits / ne posiahnu na vashu chest, ne biitesia / Zhinkam ne tym strashnyi ya." ${ }^{20}$ In any case, all women on his list lose their honor (reputation) because they are seduced by Don Juan and as a result their lives are completely destroyed. The destiny of one of the women sounds like a reference to Pedro Calderón de la Barcas famous play El medico de su honra (1637; The Surgeon of His Honor). Lesia Ukrainka's Don Juan once tried to steal "the wife of Alcaide." "But the Alcaide / Killed her and wounded Don Juan grievously."21 This reaction of the Aclaide resembles the behavior of Calderón's Don Gutierre, who kills his wife because of a misunderstanding and looming suspicions, which he takes as a threat to his reputation.

\footnotetext{
14 Ukrainka, The Stone Host, 138.

15 Ukrainka, The Stone Host, 109.

16 Ukrainka, The Stone Host, 109.

17 Ukrainka, The Stone Host, 110.

18 Ukrainka, Dueño de piedra, 219.

19 Ukrainka, The Stone Host, 107.

20 Ukrainka, Kaminnyi hospodar, 583.

21 Ukrainka, The Stone Host, 91.
} 
However, Lesia Ukrainka's concentration on the concepts of dignity and reputation (honor) does not mean imitation in order to make the drama sound Spanish. In my opinion, it is a sophisticated game with the Spanish tradition, which allows the playwright to convert the whole Don Juan legend into a philosophical theatrical work about the writer's time, her country, and herself. First of all, this concerns the problem of the power ${ }^{22}$ and freedom of an individual who questions, challenges, and destroys established values. ${ }^{23}$ In particular, Lesia Ukrainka points to the harmful consequences of individualist ethics for culture and society.

The characters of the play pay lip service to the idea that dignity should be based on a "word of honor" ${ }^{24}$ ("palabra de honor" ${ }^{25}$ ). However, in reality the picture is quite different. The first thing that draws the researcher's attention is the fact that the concept of dignity in the play is understood as a system of rules imposed by society that limit human freedom, not as a code of conduct voluntarily accepted by individuals. The consequences of this situation are fatal for Don Juan and Dolores: the man has to wear the ring, and the woman must always have a locket on her neck - symbols that serve as reminders of the decision made by their mothers when both characters had no free will (the man was a baby and the woman was not yet born). Their relationship is doomed as they live not as they wish but as tradition prescribes. The result of this existential challenge of living in hypocrisy is destructive: the characters do not keep their words. Don Juan makes promises to women to love them, but only as a trick to seduce them. In the end, he renounces the vow he has given to Dolores.

Something similar happens to Donna Anna when she becomes the Commander's wife. The promise seems to regulate their relationship and to determine their understanding of marriage as a pact about mutual obligations recognized by a married couple: "I do not bind her, God does, and the law, / And I'll have no more liberty than she," ${ }^{26}$ says the Commander. "It is not love that fears a solemn promise" ${ }^{27}$ ("No es amor que jurar teme" ${ }^{28}$ ). However, married life for both characters proves to be far from ideal. Donna Anna discovers that her husband understands dignity as formal etiquette. The young woman cannot go out to entertain herself because she has to honor the memory of her husband's uncle, who she did not even know. "Therefore you must honor the memory / of all your kins," ${ }^{29}$ - the Commander provides her with instructions.

22 Lesia Demska-Budzuliak, Drama svobody v modernismi: Prorochi holosy dramaturhii Lesi Ukrainky [The Drama of Freedom in Modernism: Prophetic Voices in Lesia Ukrainka's Dramaturgy] (Kyiv: Akademvydav, 20o9); Oksana Zabuzhko, Notre Dame D'Ukraine.

23 Abram Gozenpud, Poetychnyi teatr Lesi Ukrainky [Lesia Ukrainka's Poetic Theatre] (Kyiv: Mystetstvo, 1947).

24 Ukrainka, The Stone Host, 92.

25 Ukrainka, Dueño de piedra, 200.

26 Ukrainka, The Stone Host, 96.

27 Ukrainka, The Stone Host, 96.

28 Ukrainka, Dueño de piedra, 205.

29 Ukrainka, The Stone Host, 118. 
She has to learn that at the court her seat is near the Queen so that all courtiers can see her: "My musymo pylnuvaty ne tilky chesti, / ale i vymoh naimenshykh etykety"зo ("Hence we must need not only / Honors, but the least of rules of etiquettes / However petty" ${ }^{11}$ because “... the knightly manner, which the honor/ of the house requires"32 ("el orden tradicional necesario / para esplendor de la casa"33). Donna Anna is not sincere with the Commander. Moreover, she is a "gifted" disciple of her husband as she goes even further in breaking moral codes. She manipulates Don Gonzago at the ball in Act II and distracts the Commander's attention (consciously or unconsciously), this helping Don Juan to murder Don Gonzago in Act V. She expects the Spanish aristocrats to accept the killer of the head of their house into their family and does not feel any shame when she sees Don Juan drinking from the Commander's goblet. Donna Anna is aware of the fact that Don Juan is notagentleman "Vy, lytsarvoli, yak buly banitom, / buly bandytom"34 ("You, knightly champion of freedom, were / in banishment, a bandit"35) ("Vos sois el caballero de la libertad. Cuando fuisteis / desterrado, erais bandido"36), but this knowledge does not prevent her from putting the Commander's white coat on Don Juan's shoulders. It is an insolent act because only the King can do so.

Thus, all these characters do not keep their word. Even Dolores has to break her oath to Don Juan. The only exclusion seems to be the Commander, but he is not the kind of man to trust either. "Rights without duties are but anarchy"37 ("Prava bez oboviazkiv - to svavolia" ${ }^{8}$ ), says Don Gonzago de Mendoza. He believes that the Commander's coat came to him "for honor's sake" 39 ("por los méritos" ${ }^{\circ}$ ), in other words, as recognition of his high aristocratic morals. However, the problem is that Don Gonzago de Mendoza, if we judge him by standards of Spanish baroque drama, is a bad courtier because he dreams of occupying the King's throne.

The concept of honor (la honra) understood as reputation is also interpreted in Lesia Ukrainka's play in an original way. In contrast to 17th century Spanish baroque theatre, female characters in The Stone Host's possess much more control over their bodies and are almost indifferent to public opinion. Paradoxically enough, it is Dolores, the most "catholic" character of the play, who is the symbol of this new freedom, which feminist critics comment on frequently. ${ }^{41}$ Roman Weretelnyk stresses that the play is a

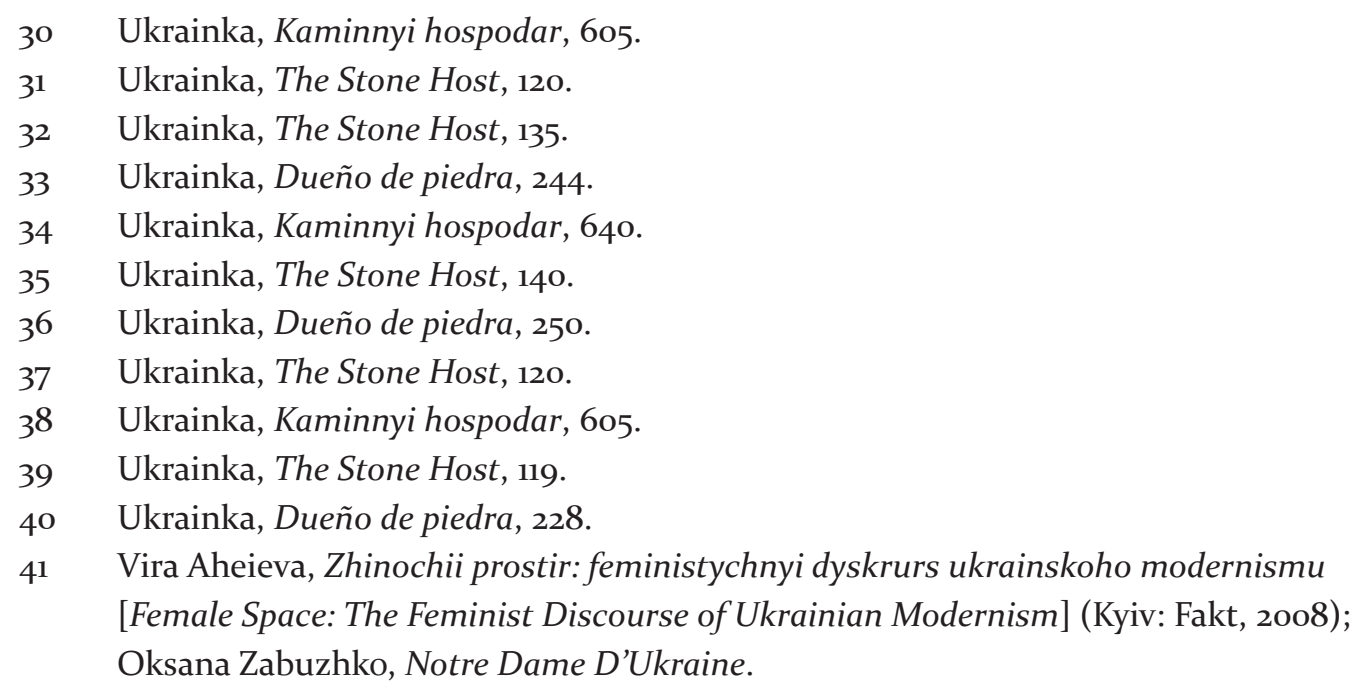


"fitting finale of Ukrainka's deconstruction of patriarchy in her works." ${ }^{42}$ The interpretation of the play in "Spanish terms" adds some important nuances to this conclusion. To explain my viewpoint, I suggest considering the use of female-to-male cross-dressing in the drama. Joe Labanyi states that "the manly woman (mujer varonil) was a stock dramatic theme"43 of Spanish baroque theatre. In many plays women are raped or violated or seduced and have to put on men's clothes in order to restore their honor (la honra). The best known examples of heroines using cross-dressing for this purpose are Doña Juana from Tirso de Molina's romp Don Gil de Calzas Verdes (1615; Don Gil with the Green Breeches) and Rosaura from Calderón's La vida es sueño (1635; Life is a Dream).

Practically all these plays end with the manly woman capitulating to marriage: there is no serious disturbance to gender roles, but there is a lot of fun and Baroque play with appearances, and in the process women's roles are greatly expanded. ${ }^{44}$

Dolores in The Stone Host uses cross-dressing twice. In Act II she appears as Black Domino - in the costume which is supposed to hide the fact that she is a woman (if not to show her as a male character). In Act III she wears the male costume of a monk - "a cloak of invisibility - a black cloak, which covers all the face - only two slits being left for the eyes." 45 This type of costume is asexual, too, but is male. In my opinion, Dolores's crossdressing is connected with the absolute freedom with which she treats the issue of women's honor (reputation). In the first case she chooses disguise in order to witness the beginning of a love affair between Donna Anna and Don Juan. In the second case she comes to a cave in Cádiz to tell Don Juan that she has paid for the decree of his reinstatement with her body. In terms of the Spanish theatre, this is extremely humiliating for a man. She will pay for the Pope's Bull by entering a monastery. It is important to stress that Dolores has lost her honor not because she has been raped. Her loss of honor is a result of her own free decision to save Don Juan's reputation. Dolores is beyond such criteria of judgment in regards to women as being "shameful" ... "honorable." "How far now / From me these words are," ${ }^{46}$ - she says (“Deshonrada” ... "honrada” ... ¡qué lejos ahora / están de mí las palabras!”47). Unlike the heroines of 17th century Spanish plays, Dolores's crossdressing does not end with marriage, rather it represents a serious disturbance of gender roles and is not fun at all.

42 Roman Weretelnyk, "A Feminist Readings of Lesya Ukrainka’s Dramas," (PhD diss., University of Ottawa, 1989), 227. Joe Labanyi, Spanish Literature. A Very Short Introduction (Oxford; New York: Oxford University Press, 2010), 84.

44 Labanyi, Spanish Literature, 84.

45 Ukrainka, The Stone Host, 112.

46 Ukrainka, The Stone Host, 114.

47 Ukrainka, Dueño de piedra, 223. 
Donna Anna also demonstrates significant freedom in making decisions which can damage her reputation. In my opinion, she is a reincarnation of the woman-mocker or prankster, a female version of a Spanish burlador (from the verb burlarse de algo or alguien - to make fun of sth/sb). It makes sense to remember that Tirso de Molina's Don Juan, termed a trickster in the English translation of the play, is a burlador a person who plays dirty tricks on women and tries the patience of God. Ana Suárez Miramón argues that “...Tirso was an outstanding creator of feminine characters, who, without using extreme situations and breaking social norms, behaved with real inner freedom." ${ }^{8} 8$ This statement seems to be exaggerated, because the Spanish playwright was a Catholic monk. He was one of the first to pay attention to women's agency in his plays but shared the traditional Christian viewpoint about them as creatures who lead men astray. As a result, he shows that when women have to take revenge for offences caused by men, they turn out to be more dangerous than their offenders. They become burladoras, a type of mulier fortis with a "malicious underside" (envés malvado). ${ }^{49}$ The best known example of this type of woman in Tirso de Molina's plays is Doña Juana from Don Gil with the Green Breeches.

However, there are some important differences between Donna Anna and Tirso's heroines, which are determined by the spirit of the end of the 19th - beginning of the 2oth centuries culture. Lesia Ukrainka's heroine, Doña Juana or even Dolores, does not have to become a manly woman or put on man's clothes to restore her honor. She is neither offended nor violated. Her ambition is not an impeccable reputation. Her goal is represented in her frightening dream. She sees herself as a young princess in a castle located on top of "a mountain sheer and inaccessible" and "no one has the power / to climb the precipice and come to her." She takes strange pleasure (I would term it sadistic) when she sees valiant knights perishing in blood, flowing in crimson rivers about the mountain foot..$^{\circ}$ This dream is a projection of Donna Anna's life's program. The Commander and Don Juan are just steps on the stairway to power: "No, my Commander is the mountain's itself / And there shall be no happy knight for me, / No, nowhere in the world." ${ }^{11}$ World literature knows many examples of similar descriptions of the loneliness associated with dictators obsessed with their thirst for power. "A glass of lemonade" cannot quench this thirst. It is a knight's reward, not Donna Anna's.

48 Ana Suárez Miramón, “El tema de la mujer en el teatro barroco," in Las mujeres escritoras en la historia de la Literatura Española, coord. por L. Montejo Gurruchaga y N. Baranda (Madrid: UNED, 2002), 68 ("Sin ninguna duda, Tirso fue el auténtico creador de personajes femeninos que, sin necesidad de recurrir a situaciones extremas y dentro del marco de la norma, se comportaban con verdadera independencia interior").

49 Francisco Florit Durán, "La dama burladora en Tirso de Molina," in La desvergüenza en la comedia española: XXXIV Jornadas de Teatro Clásico. Almagro 5, 6 y 7 de julio de 2011, coord. por Felipe B. Pedraza Jiménez, Rafael González Cañal, Elena E. Marcello (Universidad de Castilla-La Mancha, Ediciones de la Universidad de Castilla-La Mancha, 2013), 125.

$50 \quad$ Ukrainka, The Stone Host, 92-93.

$51 \quad$ Ukrainka, The Stone Host, 93. 
Thus, Lesia Ukrainka's play is about a duel ("mutual hunt") between el burlador and la burladora, in which the former is defeated by the latter, more resourceful, more courageous, more unprincipled, and more dedicated to something which seems to be more durable than love affairs - power over the world. This motif moves the play beyond the conventions of Spanish baroque theatre and a traditional understanding of "Spanishness," which always leave women in a subordinate position.

Lesia Ukrainka's focus on problems of power and female agency causes a transformation within the classical scheme of characters used in 17th century Spanish baroque drama. Dama is Donna Anna, Galán is Don Juan, and his Gracioso is Sganarel. However, other figures are either weak or absent. Viejo is Anna's father Pablo Alvarez, but his agency is almost null: he only appears onstage to bless Donna Anna's marriage to the Commander. The father does not influence his daughter's behavior or decision. She herself is responsible for her reputation even before the marriage. In the case of Poderoso, the difference is even more considerable. In 17th century Spanish theatre it is the King who symbolizes order and justice. In Lesia Ukrainka's play the King and the Queen exist offstage. The characters mention them in their conversations but the monarchs never act in person. Moreover, the King's role as Poderoso is already usurped by the Commander, who is thinking of occupying the throne together with Donna Anna.

The use of conventions from 17th century Spanish baroque drama is inseparable from the image of Spain created by Lesia Ukrainka in her play. In its general features it reproduces stereotypes about the country, disseminated in European and world culture. Stanley Payne sums them up in the introduction to his book, Spain. A Unique History:

Broadly speaking, the content of foreign images and stereotypes of Spain has changed in terms and emphases in different historical eras. These may be roughly categorized as 1) the classic Black legend stereotype of the sixteenth and seventeenth centuries; 2) "enlightened" criticism of the second half of the seventeenth and eighteenth centuries; 3) "the romantic Spain" myth of the nineteenth century; and 4) the composite stereotypes of the late nineteenth and twentieth centuries, which revived aspects of each of foregoing visions..$^{52}$

The Black legend views "Spain as cruel, bloodthirsty, sadistic, power hungry, and monstrously destructive." ${ }_{53}$ Its most disseminated symbol is the Spanish Inquisition. "Romantic Spain" is a product of strategy achieved by depicting Spain as the exotic Other, popular among German, American, and French romantic authors - it is a world

52 Stanley Payne, Spain. A Unique History (Madison: The University of Wisconsin Press, 2011), 5 .

53 Payne, Spain. A Unique History, 6. 
of Arabic fairy tales, gypsies, bandits, smugglers, corrida de toros, and flamenco dancers. "Romantic Spain" is "no more real than the Black Legend."54

To those two basic stereotypes Inman Fox adds one more extremely popular vision of Spain as a country of knights, mystics, and conquistadors. This image represents a system of values which, according to numerous Spanish traditionalist thinkers, artists, and writers, formed a code of behavior for the Castilian elites who created the Spanish Empire in the late Middle Ages to Early Modernity period. This myth was invented by Spanish historians, writers, and artists who supported the idea of Spain as a centralized country united by Madrid. In the 2oth century it was used by Francisco Franco as one of the basic concepts of his ideology, known as Francoism. ${ }^{55}$ It is important to stress that this image has become a stereotype of Spain in Ukraine. Moreover, it has gained much popularity in Ukrainian culture as a model that Ukrainian elites are impelled to imitate. Among writers who believed in this stereotype was Dmytro Dontsov and his followers, known as vistnykivtsi. They interpreted some wellknown characters of Spanish literature, such as El Cid ${ }^{56}$ and Don Quixote, ${ }^{57}$ as symbols of authentically Spanish aristocratic chivalric values. The same strategy is followed by Ostap Hrytsai when he tries to inscribe the controversial figure of Lope de Vega into this idealistic stereotypical vision of Spain..$^{8}$ The most recent example of integrating this idea into Ukrainian nation-building is Oksana Zabuzhko's book Notre Dame D'Ukraine: Ukrainka in a Conflict of Mythologies, ${ }^{59}$ in which citations from Ortega y Gasset are used to justify understanding Lesia Ukrainka as one of the few infallible knights of the Ukrainian nation.

In Lesia Ukrainka's The Stone Host one can find all three stereotypes of Spain. “The Black legend," however, plays almost no part in the drama. References to it appear twice and in both cases are connected with the Inquisition. Don Juan's list includes "a pious Abbess," "the granddaughter of the Great Inquisitor himself." ${ }^{60}$ In Act III Sganarel takes Dolores, dressed as a monk, for "a spy from the Grand Inquisition" ${ }^{1}$ ("Un espía de la Inquisición”62). The Inquisition is omnipresent and signifies something extremely frightening and terrifying. Dealing with it is dangerous. In this context the act of seducing the Great Inquisitor's granddaughter turns Don Juan into a hero in Donna Anna's eyes.

54

Payne, Spain. A Unique History, 6.

Inman Fox, La invención de España: Nacionalismo Liberal e identidad nacional (Madrid: Cátedra, 1997).

Hanna Chykalenko, “Sid, natsionalnyi heroi Espanii [Sid, Spain’s National Hero]," Vistnyk I (1937): 17-25

Dmytro Dontsov, “Sancho Panza v nashii diisnosti [Sancho Panza in Our Reality]," Vistnyk VII-VIII (1934): 575-601

Ostap Hrytsai, “Feniks Espanii (Lope de Vega) [The Phoenix of Spain (Lope de Vega)], Vistnyk I (1936): 8-17.

Zabuzhko, Notre Dame D’Ukraine, 415-17, 451-52, 483-96.

Ukrainka, The Stone Host, 90.

Ukrainka, The Stone Host, 111.

Ukrainka, Dueño de piedra, 220. 
In contrast to "the Black legend," the stereotype of "romantic Spain" reincarnates many times in the play. Judging by Don Juan's list, the country is a multicultural territory: among the victims one finds a "A Rabbi's daughter from Toledo"63 and a gypsy girl. Besides, in The Stone Host Spain is a country of bandits and smugglers. Don Juan is a smuggler. He hides in caves "living off contraband ... he sometimes went / Sailing with pirates." ${ }^{64}$ It is also worth drawing attention to the fact that Lesia Ukrainka's Cádiz is not the famous city, the center of trade with Latin America, of George Byron's description:

\section{I said that Juan had been sent to Cadiz - \\ A pretty town, I recollect it well - \\ ' $\mathrm{T}$ is there the mart of the colonial trade is \\ (Or was, before Peru learn'd to rebel), \\ And such sweet girls - I mean, such graceful ladies, \\ Their very walk would make your bosom swell. ${ }^{65}$}

It is instead a mysterious zone near the sea with many caves populated by outlaws and smugglers. In the Spanish translation, in a stage direction in Act III we read "una cueva a la orilla del mar, en la región de Cádiz." ${ }^{6}$ The translators "improved" the original because in Cádiz and this particular neighborhood there are no caves. The city is located on the peninsular with a long isthmus and is surrounded by the ocean on all sides.

In Lesia Ukrainka's approach towards representing "romantic Spain," a huge part is given to imagery related to Seville. The city itself is imagined as a bright colorful place full of life. Even the cemetery impresses with its gorgeous architecture and exuberant vegetation. It is "more beauty than sorrow." ${ }^{67}$ It is a world of folkloric dances, such as the seguidilla and fandango. Donna Anna dances both of them at the ball. The Ukrainian playwright stresses that this type of culture is a product of a combination of both Christian and Arabic components. In Act I, Don Juan's list, which has already been cited several times, mentions a Moorish girl "that poisoned her brother" and "later became a nun." ${ }^{6}$ In Act II, a "Moorish style," ("el estilo moro") becomes the dominant element of the scenery and props: the patio looks Moorish, ${ }^{69}$ Don Juan wears a Moorish dress, sings a Moorish song and bows in the Oriental manner. Donna Anna tries to hurt Don Juan's feelings by saying that his behavior as a whole (not only his

63 Ukrainka, The Stone Host, 90.

64 Ukrainka, The Stone Host, 89.

65 George Gordon Byron, Don Juan. Canto the Second, accessed October 18, 2020, http:// gutenberg.net.au/ebookso7/o70o141h.html\#aii.

66 Ukrainka, Dueño de piedra, 220.

67 Ukrainka, The Stone Host, 90.

68 Ukrainka, The Stone Host, 89.

69 To compare how "authentically" Lesia Ukrainka represents the Moorish style of the patio I recommend to visit the web-page of Casa del Rey Moro de Seville, a house of the 15th-16th centuries, accessed October 18, 2020 https://es.wikipedia.org/wiki/Casa_del_ Rey_Moro_(Seville)\#/media/Archivo:Casa_del_Rey_Moro,_Seville._Patio.jpg. 
presentation at the ball) is just a rude imitation of freedom - "the Mooring style,"7o or morería, as the translators of the play into Spanish render it. ${ }^{71}$ Nevertheless, she enjoys it as entertainment and interprets it as confirmation of her superiority over the man.

A letter addressed to Marharyta Komarova sheds light on Lesia Ukrainka's understanding of oriental exoticism. Lesia Ukrainka stresses how annoying stereotypical representations of the Arabic world are: monkeys jumping on a fence to the sounds of a pipe, women performing belly dances, an old dervish swinging his head distracts her from writing. One of the remedies to calm her nerves is to learn Spanish. ${ }^{72}$ To a large extent, Lesia Ukrainka's reaction to touristic Egypt is a reminder of Donna Anna's skeptical attitude to Don Juan's Moorish masquerade ("You chose the song to suit the costume, then?"73). The remark indicates that Donna Anna trusts the orientalist imagery of Spain just as Lesia Ukrainka does not accept Arabic stereotypes.

The third chivalric and mystical stereotype of Spain is personified in the drama by the Commander and his family. It is important to emphasize that Lesia Ukrainka defines their mode of living as Castilian. By doing so the Ukrainian playwright argues that Spain, as a nation, has a hybrid identity, which, in my opinion, is convincing evidence of Lesia Ukrainka's sensitivity to cultural nuances. The Castilian style is strict, severe, and uptight. In Act IV Anna's boudoir is “a large room opulently furnished but in dark tones. ... Donna Anna in a grey dress with black half-mourning sits at a small dressing table arranging her jewels in a box and trying them on, looking in the mirror." 74 The cemetery monuments in Act V "are mostly made from dark stone in a heavy style," "no plants, no flowers." 75 The statue of the Commander is large and magnificent. The banquet hall at the Commander's mansion in Act VI does not provide any space for entertainments or dances:

Not very big but beautifully decorated with carved cabinets, sideboards with valuable plate, suits of armor, etc. In the middle is a long table set for a ceremonial supper, around it stand oak chairs in a heavy style. ${ }^{76}$

This is how Lesia Ukrainka imagines the interiors of houses of the Castilian aristocracy. They reflect the values of their owners - as sober, reserved, and pompous people.

A comparison of the Andalusian and Castilian variants of Spanish national identity permeate the first two acts of the play. The Commander does not understand all the details of the southern culture and makes judgements about them according to

$\begin{array}{ll}70 & \text { Ukrainka, The Stone Host, } 109 . \\ 71 & \text { Ukrainka, Dueño de piedra, } 217 \\ 72 & \text { Ukrainka, Lysty: 1903-1913, 665-66. } \\ 73 & \text { Ukrainka, The Stone Host, } 102 . \\ 74 & \text { Ukrainka, The Stone Host, } 118 . \\ 75 & \text { Ukrainka, The Stone Host, } 126 . \\ 76 & \text { Ukrainka, The Stone Host, } 134 .\end{array}$


Castilian rules. In Act I this makes him suppose that etiquette in Seville is even stricter "than at the Castilian Court." At the same time, he is surprised by the fact that Donna Anna emerges without dueñas. In Act II Don Gonzago de Mendoza criticizes the freedom of Donna Anna's behavior when she does not want to join him before the ball: "At home in Castile / Fiances never werealone together" 77 ("En Castilla no hay costumbre de que los novios se queden a solas"78). He cannot appreciate the beauty of the lyrics of Don Juan's song and thinks that "the refrain is out of place."79 In my opinion, Lesia Ukrainka's intention is to make the poem sound "Moorish" as much as possible, this refrain being a key stylistic device to achieve the goal. It resembles kharja, the final refrain of muwashshah, a lyric genre of Islamic Iberian poetry. It appears at the end of each stanza. "Moorish style demands it be there," explains Don Juan. Donna Anna uses the Commander's unfamiliarity with local Andalusian customs to cheat on him: she explains that Don Juan's kneeling on his knee in public before her is decent because the local tradition allows $\mathrm{it}^{80}$. When Donna Anna gets married to the Commander and moves to Madrid, she seems to be reconciled with severe and stony Castilian etiquette but she still misses the freedom of Seville. Mariquita expresses nostalgia in Act IV. When opening the shutters, she looks at the streets of Madrid and fetches a deep sigh: "For this is not Seville!... But here the air is stony..." ${ }^{81}$

Thus, the hetero-image of Spain is based on the following stereotypes: 1) Spaniards are smugglers' and bandits, 2) Andalusia (Seville) is a land of freedom and joy and a product of Christian and Moorish as well as some other ethnic cultural elements, and 3) Spanishness is seen as a system of values produced by the Castilian elites in the Late Middle Ages and Early Modern periods. This complex image is important for understanding the spatial poetics of The Stone Host. Built up in a vertical dimension, the geographical imagery of the play, represented by stereotypes of Spanishness, reflects the mapping of spaces of freedom in the artistic world of Lesia Ukrainka's drama. Cádiz is a territory of absolute anarchy where the agency of the characters is not controlled by any laws. Don Juan escapes from there after committing his dishonorable acts. To a great extent, he is not the Don Juan of Seville but the Don Juan of Cádiz - a unique case in world literature. Cádiz is a part of Andalusia, like Seville, but the difference between the two loci is striking. If Cádiz is a hell, a land of terror and barbarity, Seville in the play is located on the frontier of the civilization controlled by Castile. It is a porous limitrophe zone producing tricksters like Donna Anna, capable of anything in a struggle for power. Madrid, the capital, is a dead space of the court with its hegemony of false etiquette - it destroys the freedom of individuals by seducing them with ambitions to usurp the King's crown. Donna Anna is torn in two trying to make a choice between anarchy and stony etiquette, and in the end she makes

\footnotetext{
$77 \quad$ Ukrainka, The Stone Host, 99.

78 Ukrainka, Dueño de piedra, 207.

79 Ukrainka, The Stone Host, 102.

8o Ukrainka, The Stone Host, 110.

$81 \quad$ Ukrainka, The Stone Host, 232.
} 
her choice in favor of the second alternative because it leads her to absolute power, although it costs her too high a price - she becomes la mujer-burladora, who is ready to pass from anarchy to the despotism of a dictator.

To conclude, The Stone Host has proved to be a genuine Spanish play. It is not only another presentation of the legend of Don Juan but a sophisticated modernist play, which skillfully develops traditions of 17 th century Spanish baroque drama and plays with popular stereotypes of Spanishness. However, the "Spanish code" brings something more profound and important to the play than romantic exoticism. Ttraditional Spanish sensitivity to issues of dignity, reputation, and chivalric values serves as a prism through which the playwright examines the world around her. The picture is horrible: the universe deserves complete destruction because no one keeps his/herword nor cares about his/her reputation. The only concern is power. Punishment of the protagonists brings no catharsis. Lesia Ukrainka created an astonishing modernist tragicomedy of dishonesty, full of the spirit of uncertainty.

\section{Bibliography}

Aheieva, Vira. Zhinochii prostir: feministychnyi dyskrurs ukrainskoho modernismu [Female Space: The Feminist Discourse of Ukrainian Modernism]. Kyiv: Fakt, 2008.

Arellano, Ignacio. Historia del teatro español del siglo XVII. Quinta edición. Madrid: Cátedra, 2012.

Bakhtin, Mikhail. Problems of Dostoevsky's Poetics. Minneapolis; London: University of Minnesota Press, 1984.

Bohovin, Olha. "Krytychna retseptsiia dramy Lesi Ukrainky 'Kaminnnyi hosopdar' u XXXXI st.: istoriohrafichni pytannia [Critical Reception of Lesia Ukrainka's The Stone Host in the 2oth and the 21st Centuries: Historiographical Issues]." Naukovi zapysky Natisonalnoho universytetu Ostrozka akademiia. Seriia Filolohichna 41 (2014): 202-o6.

Byron, George Gordon. Don Juan. Canto the Second. Accessed October, 18, 2020. http:// gutenberg.net.au/ebookso7/o70o141h.html\#aii.

Chykalenko, Hanna. "Sid, nationalnyi heroi Espanii [Sid, Spain’s National Hero]." Vistnyk I (1937): 17-25.

Demska-Budzuliak, Lesia. Drama svobody v modernizmi: Prorochi holosy dramaturhii Lesi Ukrainky [The Drama of Freedom in Modernism: Prophetic Voices in Lesia Ukrainka's Dramaturgy]. Kyiv: Akademvydav, 2009.

Dontsov, Dmytro, "Sancho Panza v nashii diisnosti [Sancho Panza in Our Reality]." Vistnyk VII-VIII (1934): 575-601.

Florit Durán, Francisco "La dama burladora en Tirso de Molina." In La desvergüenza en la comedia española: XXXIV Jornadas de Teatro Clásico. Almagro 5, 6 y 7 de julio de 2011, coord. por Felipe B. Pedraza Jiménez, Rafael González Cañal, Elena E. Marcello, 123-43. Universidad de Castilla-La Mancha, Ediciones de la Universidad de Castilla-La Mancha, 2013.

Fox, Inman. La invención de España: Nacionalismo Liberal e identidad nacional. Madrid: Cátedra, 1997.

Gozenpud, Abram. Poetychnyi teatr Lesi Ukrainky [Lesia Ukrainka's Poetic Theatre]. Kyiv: Mystetstvo, 1947.

Hrytsai, Ostap. "Feniks Espanii (Lope de Vega)" [The Phoenix of Spain (Lope de Vega)]. Vistnyk I (1936): 8-17.

Karpiak, Robert. “Don Juan in Slavic Drama." PhD diss., University of Ottawa, 1977. 
Kukhar, Roman. Do dzherel dramaturhii Lesi Ukrainky [On the Origins of Lesia Ukrainka's Dramas]. Nizhyn: Nizhynskyi derzhavnyi pedahohichnyi universytet im. M. Hoholia, 200.

Labanyi, Joe. Spanish literature. A Very Short Introduction. Oxford; New York: Oxford University Press, 2010.

Lesia Ukrainka. Kaminnyi hospodar [The Stone Host. Dramatic Poems]. In Orhiia. Dramatychni poemy by Lesia Ukrainka, 545-642. Kyiv: Osnovy, 2001.

Lesya Ukrainka. The Stone Host, translated by Vira Rich. In Constantine Beda, Lesya Ukrainka. Life and Works, 87-142. Toronto: University of Toronto Press, 1968.

Lesia Ukrainka. Dueño de piedra. In Lesia Ukraïnka in Translations, edited by Natalia Pazuniak, 195-252. Philadelphia: The Commemorative Committee to Honor Lesia Ukrainka, 1988.

Lesia Ukrainka. Lysty: 1903 -1913 [Letters, 1903-1913]. Kyiv: Komora, 2018.

Nenadkevych, Yevhen. "Ukrainska versiia svitovoii temy pro Don Juana v istoryko-literaturnii perspektyvi [The Ukrainian Version of the Universal Legend of Don Juan from the Literary and Historical Perspectives]." In Tvory by Lesia Ukrainka, edited by Borys Yakubskyi, vol. 11, 7-42. Kyiv: Knyhospilka, 1929.

Payne, Stanley. Spain. A Unique History. Madison: The University of Wisconsin Press, 2011.

Polishchuk, Yaroslav, and Anatolii Krylovets, eds. Kaminnyi hospodar Lesi Ukrainky i fenomen Seredniovichchia [The Stone Host by Lesia Ukrainka and the Phenomenon of the Middle Ages]. Rivne: Perspektyva, 1998.

Reda, Marta. “Obraz Don Juana u tvorchosti Lesi Ukrianky u konteksti yevropeiskoi donzhuaniany [The Image of Don Juan in the Works of Lesia Ukrainka in the Context of the European Tradition of the Don Juan Legend]." Roczniki Humanistyczne, tom LIV-LV, zeszyt 7 (2006-2007): 83-95.

Rozumnyi, Yaroslav. "Vid 'sevilskoho oshukantsia' do ukrainskoho Don Juana” [From the Trickster of Seville to the Ukrainian Don Juan]." Slovo i chas 6 (1993): 25-29.

Suárez Miramón, Ana. "El tema de la mujer en el teatro barroco." In Las mujeres escritoras en la historia de la Literatura Española, coord. por L. Montejo Gurruchaga y N. Baranda, 55-84. Madrid: UNED, 2002.

Weretelnyk, Roman. “A Feminist Readings of Lesia Ukrainka’s Dramas.” PhD diss., University of Ottawa, 1989.

Zabuzhko, Oksana. Notre Dame D’Ukraine: Ukrainka v konflikti mifologiy [Notre Dame D'Ukraine: Ukrainka in a Conflict of Mythologies]. Kyiv: Fakt, 2007.

Zhuravska, Ida. Lesia Ukrainka i zarubizhni literatury [Lesia Ukrainka and Foreign Literatures]. Kyiv: Vydavnytstvo Akademii Nauk Ukrainy, 1963.

\section{(2)}

Oleksandr Pronkevich, Dr., Prof., Dean of Philology at Petro Mohyla Black Sea National University, President of the Association of Hispanists of Ukraine, member of the Ukrainian Association of the Fulbright Academic Exchange Program Alumni and the International Association of Hispanists; Fulbright Scholar, University of Wisconsin-Madison (2003-2004), alumnus of an academic exchange program financed by the Spanish Government, University of the Basque Country, Alava, Spain (2005), Visiting Professor at the University Montclair, New Jersey, USA (2011). Oleksandr Pronkevich is a leading researcher and a member of research teams on number of international and Ukrainian research projects financed by governments of Spain, Poland, Germany, and Ukraine. Professor Pronkevich is the author of more than 150 papers and 9 books. His main fields of research interests are Spanish literature and the Spanish-Ukrainian cultural dialog. 